\title{
PENGARUH FAKTOR PSIKOGRAFIS TERHADAP KEPUTUSAN PEMBELIAN SEPATU MEREK MOLLINIC DI PT. RAMAYANA LESTARI SENTOSA, TBK PADANG
}

\author{
Fisesra, Febsri Susanti \\ Sekolah Tinggi Ilmu Eknomi "KBP" \\ febsrisusanti@akbpstie.ac.id
}

\begin{abstract}
This study aims to determine whether there is influence of psychographical factors consisting of lifestyle, personality and social class on the purchase decision of mollinic brand shoes on pt Ramayana lestari sentosa tbk padang.

Technique of data collecting is done by way of 100 concurrent spreading at consumer who buy mollinic brand shoes which is in ramayan lestari sentosa tbk padang. The analysis tools used are validity test, reliability test, descriptive analysis, classical assumption test, multiple regression analysis and hypothesis test. Data is processed through spss application 16. The result of regression equation is obtained: $Y=3,468+0,338 X 1+0,382 X 2+0,103 X 3+e$

Based on the results of the analysis of the calculated f count of 66.072 significant $0.000 a$, adjusted $R$ square value is 0.664 and hypothesis test through $t$ test on lifestyle obtained tcount $(4,728)>t$ table 1.660 , terhepap personality titung (4.302)> t table and against social class is tcount $1.128<$ ttabel 1.660 it can be concluded from the three variables, lifestyle and personality variables that have a positive and significant influence in purchasing decisions and social class has no positive effect on purchasing decisions.
\end{abstract}

Keywords: lifestyle, personality, social class and purchase decision 
PENDAHULUAN

\section{Latar Belakang}

Perkembangan ekonomi akan dipengaruhi oleh pertumbuhan penduduk yang semakin banyak. Hal tersebut dikarenakan semakin meningkatnya kebutuhan akan produk atau jasa yang diperlukan masyarakat. Dengan kondisi tersebut, tentu saja sangat membuka peluang bagi para pebisnis dan kesempatan ini dimanfaatkan oleh para produsen untuk menghasilkan produk baru yang benilai bagi konsumen.

Pertumbuhan ekonomi yang pesat ini meningkatkan dan bertambahnya produk atau jasa di lingkungan masyarakat sehingga masyarakat dituntun untuk cermat dalam memilih atau menentukan pembelian atas produk atau jasa yang ingin digunakan.

Dalam memutuskan untuk membeli, konsumen juga harus memperhatikan di tempat mana mereka harus melakukan pembelian produk atau tersebut, dalam penelitian ini,penulis menjalankan penelitian di PT. Ramayana Lestari Sentosa,Tbk Padang. Ramayana merupakan bagian perusahaan retail yang menyediakan bermacam-macam produk diantara nya produk pakaian, sepatu, koper, dan lainya. Produk atau brend yang dipasarkan oleh PT. Ramayana antara lain seperti JB Boss, West, Nike, Adidas, Yongki Kumaladi, Kardinal, Lois, Laviola, Calbi, Dr. Kevin, Eager, Rei, President tas, Exsport, Frea, Modello, Ball Moral, Watchout, Triset, Filla, Ardiles, New Era, Kasogi, Weston, Precise, Bata, Tomkin, Leuge, Sportetion, The Britano, Banhill, MGEE, Carvil, Batik Artaloka, Emba, Triple, Mollinic dan banyak brend lainnya.

Kebutuhan untuk memperoleh suatu produk atau jasa harus sama dengan yang diinginkan oleh konsumen, keputusan yang dilaksanakan oleh konsumen untuk melakukan pembelian sebuah produk, merupakan sebuah langkah untuk memilih dari berbagai alternatif yang sesuai untuk menyelesaikan masalah dengan tindakan nyata.
Pembelian atas produk atau jasa sangat dipengruhi oleh perilaku konsumen, maka hal tersebut harus diperhatikan dalam melakukan penjualan. Keputusan tersebut adalah keputusan calon pembeli untuk memilih produk yang terpat.

Upaya calon pembeli untuk menentukan jati diri ini bersangkutan sebagaimana mereka menampilkan dirinya, dan kehadirannya diterima secara umum maupun khusus oleh masyarakat atau teman-temannya. Demi mendapatkan pengakuan tersebut mereka bersedia melakukan bagaimana upaya meskipun untuk mencapainya membutuhkan biaya yang mahal. bersangkutan dengan kelas sosial dan gaya hidup, calon pembeli mencari referensi yang cocok dengan kepribadian mereka. Begitu pula dengan pembelian produk, mereka akan mencari yang cocok dengan kelas sosial, gaya hidup dan kepribadian mereka.

Keputusan pembelian adalah perilaku konsumen dalam usaha memenuhi kebutuhan dan keinginan merupakan proses penentuan sikap atau pembelian terhadap produk atau jasa, agar dapat menentukan perilaku konsumen diperlukan langkah-langkah, karena setiap saat manusia bisa berubah. Perubahan akan berpengaruh langsung kepada pola perilaku konsumen yaitu faktor variabel segmentasi psikografi yang meliputi gaya hidup, kepribadian, kelas sosial.

Minat manusia dipengaruhi oleh gaya hidup, yang mencerminkan gaya hidup tersebut dilihat dari pembelian jenis produk mereka. Dalam memasarkan produk para marketing harus memperhatikan faktor dari gaya hdiup tersebut. Seseorang memiliki gaya hidup yang berbeda-beda tergantung gaya hidup orang tersebut.

Orang yang selalu berusaha mengikuti perkembangan produk masa kini untuk mengutamakan gaya hidup meskipun mengeluarkan biaya yang cukup banyak demi mencerminkan gaya hidupnya.

Keperibadian merupakan faktor yang dapat mempengaruhi keputusan 
pembelian konsumen terhadap suatu produk. Setiap orang memiliki kepribadian yang berbeda yang mempengaruhi perilaku pembeliannya, dengan memahami karakteristik kepribadian konsumen akan sangat bernilai bagi produsen. Kepribadian biasanya dijelaskan melalui ciri-ciri meliputi kualitas, sifat, pembawaan, kemampuan bersosialisasi, dan perangai khusus, variabel ini sangat penting dalam menganalisis perilaku konsumen, apabila jenis kepribadian tersebut dapat dikelompokan dengan tepat dan terdapat korelasi yang kuat antara jenis kepribadian dalam memilih jenis produk atau merek.

Kelas sosial tergolong kepada pengelompokkan atas orang-orang yang perpendapatan sama yang akan berprilaku perilaku sesuai dengan posisi mereka di pasar. Kelas sosial dipengaruhi oleh beberapa faktor yaitu kriteria kelahiran, kualitas atau mutu pribadi, prestasi, pemelikikan atau kekayaan. Sering juga memiliki pendapat mengenai antara satu jenis produk dengan produk lain yang dianggap labih baik.

Akan tetapi, apakah faktor psikografi berupa gaya hidup, kepribadian dan kelas sosial dapat berpengaruh signifikan terhadap keputusan pembelian merek mollinic, atas dasar itulah penulis melakukan penelitian dengan mengangkat judul "Pengaruh Faktor Psikografis Terhadap Keputusan Pembelian Sepatu Merek Mollinic di PT. Ramayana Lestari Sentosa,Tbk Padang".

\section{Rumusan Masalah}

Berdasarkan uraian di atas, dapat dirumuskan sebuah permasalahan penelitian yang akan dibahas yaitu :

1. Seberapa besar pengaruh gaya hidup terhadap keputusan pembelian sepatu merek Mollinic di PT. Ramayana Lestari Sentosa, Tbk. Padang ?

2. Seberapa besar pengaruh kepribadian terhadap keputusan pembelian sepatu merek Mollinic di PT. Ramayana Lestari Sentosa, Tbk. Padang ?
3. Seberapa besar pengaruh kelas sosial terhadap keputusan pembelian sepatu merek Mollinic di PT. Ramayana Lestari Sentosa, Tbk. Padang ?

\section{Tujuan Penelitian}

Adapun tujuan dari penelitian ini adalah :

1. Untuk menganalisis pengaruh gaya hidup terhadap keputusan pembelian Sepatu merek Mollinic di PT. Ramayana Lestari Sentosa, Tbk. Padang.

2. Untuk menganalisis pengaruh kepribadian terhadap keputusan pembelian Sepatu merek Mollinic di PT. Ramayana Lestari Sentosa, Tbk. Padang.

3. Untuk menganalisis pengaruh kelas sosial terhadap keputusan pembelian Sepatu merek Mollinic di PT. Ramayana Lestari Sentosa,Tbk Padang.

\section{Manfaat Penelitian}

Dari penelitian yang dilakukan diharapkan dapat memberikan manfaat sebagai berikut :

\section{Manfaat teoritis}

Sebagai pedoman atau masukan dalam peningkatan penjualan serta mengetahui bagaimana pengaruh faktor psikografis yang terdiri dari gaya hidup dan kepribadian terhadap keputusan pembelian di PT.Ramayana LestariSentosa, TbkPadang.

\section{Manfaat praktis}

Secara praktis, penelitian ini sebagai bahan masukan untuk perusahaan Sepatu Mollinic bagaimana pengaruh faktor psikografis yang terdiri dari gaya hidup dan kepribadian terhadap keputusan pembelian di PT.RamayanaLestariSentosa, TbkPadang.

\section{Teori Keputusan Pembelian}

Dalam usaha mengenal konsumen, perusahaan perlu memahami perilakuperilaku konsumen yang merupakan wujud dari jiwa manusia dalam kehidupannya. Pendapat orang lain dan arahan-arahan internal akan berinteraksi untuk 
menentukan keputusan terakhir yang dianggap paling sesuai. Menurut Kotler (2009:166) dalam Primadhany kartana putri (2011), perilaku konsumen adalah belajar mengenai tentang individu, kelompok atau organisasi menentukan, membeli, memakai dan bagaimana barang, jasa, ide atau pengetahuan untuk memuaskan keinginan mereka. Sedangkan menurut Sumarwan (2004:26) dalam Ainun Jariah (2012) yaitu Perilaku konsumen ialah semua kegiatan, tindakan, serta langkah psikologis yang mendukung perbuatan tersebut, pada saat belum membeli, sedang memakai, menghabiskan produk atau jasa setelah melakukan pengevaluasian.

Dalam perilaku konsumen tersebut, karakteristik konsumen dan proses pengambilan keputusan menimbulkan keputusan pembelian tertentu. Menurut Fandy Tjiptono (2007:20), dalam Rozikin, Hasiolan, \& Haryono (2015) Proses pengambilan keputusan pembelian merupakan langkah pertama dari mengenal masalah yang bisa diselesaikan dengan cara membeli beberapa produk.

Langkah keputusan pembelian tidak sekedar melihat faktor- faktor yang akan memengaruhi pelanggan, Menurut Kotler (2001:226), dalam Ainun Jariah (2012). Keputusan pembelian adalah dimana konsumen benar-benar membeli produk dalam proses pengambilan keputusan pembelianya. Dalam keputusan membeli barang konsumen sering kali tidak terlibat dua pihak dalam langkah melakukan pembelian. dasarnya terdapat enam peran diperagakan oleh satu orang saja.

Keenam peran tersebut meliputi :
a. Pemrakarsa
b. Pembawa pengaruh
c. Pengambil keputusan
d. Pembeli
e. Pemakai
f. Penilai
Menurut Kotler (2001:222), dalam Ainun Jariah (2012). Sekurangnya ada lima tahap dalam langkah keputusan

pembelian, yaitu mengenal kebutuhan, mencari informasi, evaluasi beberapa alternatif, keputusan pembelian, dan perilaku paksa pembelian. Model ini mempunyai tanggapan bahwa para konsumen melakukan lima langkah dalam pembelian. Kelima langkah tersebut tidak selalu terjadi, jika pembelian tidak mementingkan masalah yang besar dan konsumen bisa melewati tahap yang tidak sesuai.

\section{Teori Gaya Hidup}

Gaya Hidup Menurut Kotler (2001 : 208) dalam Ainun Jariah (2012) adalah pola kehidupan seseorang seperti yang diperlihatkannya dalam aktivitas, minat, dan opininya". sehingga menggambarkan keseluruhan diri seseorang yang berinteraksi dengan lingkungannya.

Sedangkan menurut Setiadi (2010:148) dalam Edi satria (2015) Gaya hidup didefinisikan sebagai, cara hidup bagaimana orang menghabiskan waktu mereka, apa yang mereka pikirkan tentang diri mereka dan juga lingkungannya.

Adapun indikator dari gaya hidup antara lain aktifitas, minat, dan Opini. Gaya hidup memperlihatkan tingkah laku dan berinteraksi seseorang secara keseluruhan di dunia.

\section{Teori Kepribadian}

Menurut Kotler (2001:211) dalam Ainun jariah (2012) Kepribadian adalah perilaku unik seseorang yang memperoleh tanggapan yang relatif sama dan tetap pada pendiriannya.

Sedangkan menurut Schiffman dan Kanuk (2008:107), dalam (Fausiana Abd. hamid) Kepribadian adalah sifat kejiwaan dalam diri seseorang yaitu kualitas, sifat, pembawaan, kemampuan membujuk orang, dan peran khusus yang membedakan antar individu.

Adapun indikator dari kepribadian yang sangat berguna dalam menganalisa prilaku konsumen antara lain kualitas,sifat, pembawaan kemampuan bersosialisasi, dan perangai khusus. 


\section{Teori Kelas Sosial}

Menurut Sumarwan (2004:218), dalam Ainun Jariah (2012). Kelas sosial adalah bentuk lain dari pengelompokkan masyarakat ke dalam kelas atau kelompok yang berbeda.

Sedangkan menurut Kotler, (2005:

203). Dalam Rozikin,Hasiosan \& Haryono, (2015). Kelas sosial adalah pembagian masyarakat yang relative sama dan permanen, yang tersusun secara hirarkis dan yang para anggotanya menganut nilai, minat, dan perilaku yang serupa.

Menurut Talcott Persons (2010:154), dalam Rozikin,Hasiosan \& Haryono, (2015). indikator dari variabel kelas sosial antara lain :

a. Kriteria kelahiran

b. Kualitas atau mutu pribadi

c. Prestasi

d. Pemilikan atau kekayaan

Kategori kelas sosial biasanya disusun dalam bentuk status yang tertinggi sampai yang terendah.

\section{Kerangka Konseptual}

Penelitian ini menganalisis faktor psikografis terhadap keputusan pembelian sepatu Mollinic di PT. Ramayana Lestari Sentosa, Tbk. Padang. Untuk memperjelas faktor-faktor yang mempengaruhi keputusan pembelian dapat dilihat pada bagan berikut:



Gambar 2.1

Kerangka Konseptual

\subsection{Hipotesis Penelitian}

Adapun hipotesis dalam penelitian ini adalah :

1. Diduga Gaya hidup berpengaruh terhadap keputusan pembelian Sepatu Mollinic di PT. Ramayana Lestari Sentosa, Tbk. Padang.
2. Diduga Kepribadian berpengaruh terhadap keputusan pembelian Sepatu Mollinic di PT. Ramayana Lestari Sentosa, Tbk. Padang.

3. Diduga Kelas Sosial berpengaruh terhadap keputusan pembelian Sepatu Mollinic di PT. Ramayana Lestari Sentosa, Tbk. Padang.

\section{Jenis Penelitian}

\section{METODE PENELITIAN}

Jenis penelitian yang dipakai adalah penelitian kuantitatif yang bersifat hubungan kausal, melalui perhitungan ilmiah yang berasal dari sampel orang orang atau penduduk yang diminta jawaban atas sejumlah pertanyaan.

Menurut Sugiyono (2008: 36) dalam Ainun Jariah (2012) Menyampaikan bahwa penelitian assosiatif adalah penelitian yang bersifat menanyakan kaitan antar variabel-variabel, dan hubungan kausal adalah yang bersifat sebab akibat.

\section{Populasi dan Sampel}

\section{Populasi}

$$
\text { Menurut Sugiyono }
$$

Populasi adalah lingkungan generalisasi yang terdiri obyek atau subyek yang memiliki kualitas dan karakteristik tertentu yang ditentukan oleh peneliti untuk dipahami dan selanjutnya membuat kesimpulan, kecuali seseorang ingin meneliti seluruh bagian yang berada pada lingkungan penelitian, Dalam penelitian ini populasi diambil dari seluruh konsumen yang membeli produk sepatu molinic di PT Ramayana Lestari Sentosa Tbk Padang. Menurut data PT Ramayana Lestari Sentosa Tbk padang jumlah konsumen dari tahun 2016 sampai tahun 2017 adalah 3899 konsumen.

\section{Sampel}

Menurut Sugiyono (2012:81), sampel merupakan sebagian dari banyaknya populasi dan karakteristik yang didapat dalam populasi tersebut. jika populasi besar, maka populasi tidak mungkin dipelajari semuanya, disebabkan 
kurangnya dana, tenaga dan waktu. Dengan teknik probability sampling yaitu proportionate stratified random sampling dalam penelitian ini sampel diambil dengan menggunakan rumus slovin sebagai berikut:

$$
n=\frac{N}{1+N \cdot e^{2}}
$$

Dimana:

$\mathrm{n}=$ jumlah sampel

$\mathrm{N}=$ jumlah populasi

$\mathrm{E}=$ eror level (tingkat kesalahan) umunya digunakan $1 \%$ atau $0.01,5 \%$ atau 0.05 dan $10 \%$ atau 0,1 (catatan dapat dipilih oleh peneliti).

$$
n=\frac{3899}{1+3899 .(0,1)^{2}}
$$

$\mathrm{n}=99.97$ digenapkan menjadi 100

maka, dalam penelitian ini jumlah sampel sebanyak 100 responden.

\section{HASIL PENELITIAN}

\section{UJI Normalitas}

Uji normalitas menurut Singgih santoso, (2012:361) dalam Ainun Jariah, (2012) Dapat dilakukan dengan cara melihat normal probability plot pada output SPSS, bila hasil penyebaran data terdapat disekitar garis lurus diagonal maka persyaratan normalitas terpenuhi.

Apabila distribusi data normal, maka plot akan menyebar berbeda disepanjang garis $45^{\circ}$. pada grafik plot normal (gambar 4.2) dilihat bahwa plot menyebar berada disamping $45^{\circ}$ maka bisa diartikan bahwa data secara normal berdistribusi. Ini dapat digambarkan dibawah ini :
Gambar 4.2

\section{Hasil Grafik Uji Normalitas}



Sumber : SPSS 16 (Lampiran 3)

Gambar 4.2 diatas dapat diketahui bahwa penyebaran titik - titik berada disekitar garis diagonal dan mengikuti arah garis tersebut. Hal ini dapta dijelaskan bahwa uji asumsi normalitas telah dipenuhi.

\section{Uji Multikolinieritas}

Uji multikoliearitas digunakan untuk melihat apakah dalam suatu model terjadi kesamaan antara variabel-variabel independen. Dengan melihat out put SPSS pada table coefficients dapat diketahui data memenuhi syarat atau tidak multikolinieritas, jika nilai VIF (Variance Inflantion Factor) dibawah angka 10 $(\mathrm{VIF}<10)$ berarti tidak terjadi multikolinieritas. (Sugiyono, 2009:139) dalam Ainun Jariah, (2012).

Pada penelilian ini uji multikolinieritas menggunakan VIF. Jika VIF yang dihasikan diantara 1-10 maka tidak terjadi multikolinieritas Hasil uji multikolinearitas bisa diketahui pada tabel dibawah ini:

Tabel 4.8

Hasil Uji Multikolinieritas

\begin{tabular}{|ll|l|l|}
\hline \multirow{2}{*}{ Model } & & \multicolumn{2}{|l|}{ Collinearity Statistics } \\
\cline { 3 - 4 } & & Tolerance & VIF \\
\hline 1 & (Constant) & & \\
& x1 & .636 & 1.572 \\
& x2 & .294 & 3.401 \\
& x3 & .298 & 3.356 \\
\hline
\end{tabular}

Sumber : Data diolah SPSS 16 ( Lampiran 3) 
hasil analisis, didapat dua variabel Independen dalam penelitian ini nilai VIF gaya hidup, kepribadian, dan kelas sosial dibawah sepuluh, dan nilai tolerance nya mendekati satu. Maka dapat dikatakan tidak terjadi multikolinieritas antara variabel bebas tersebut. gaya hidup, kepribadian, dan kelas sosial memenuhi persyaratan asumsi klasik tentang multikolinieritas.

\section{Uji Heteroskesdatisitas}

Model regresi yang tepat adalah tidak terjadi heteroskesdatisitas. Menurut Mudrajad Kuncoro (2007:96), dalam Ainun Jariah, (2012) heteroskedastisitas keluar jika terjadi kesalahan atau residual dari model yang diteliti tidak mempunyai varians yang sama antar observasi. Keterangan diatas dapat digambarkan sebagai berikut :

\section{Gambar 4.3}

\section{Hasil Gambar Grafik \\ Heteroskesdatisitas}



Sumber : SPSS 16 (Lampiran 3)

Gambar 4.3 diatas dapat dilihat menunjukan, tidak terdapat pola yang berbentuk dan grafik memperlihatkan plot menyebar. Ini menjelaskan bahwa variabel bebas adalah gaya hidup (X1), kepribadian (X2), dan kelas sosial (X3) terbebas dari heteroskesdatisitas.

\subsubsection{Uji Linear Berganda}

Analisis regresi berganda dilakukan untuk melihat sejauh mana pengaruh variabel bebas pada penelitian ini memiliki pengaruh terhadap variabel terikatnya. Perhitungan analisis data pada penelitian ini dilakukan analisis statistik manual dan pengolahan data dengan SPSS 16. Nilai hasil perhitungan terlihat pada tabel dibawah ini:

\section{Tabel 4.9}

\section{Hasil Uji Linear Berganda}

\begin{tabular}{|cl|l|l|l|}
\hline \multirow{2}{*}{\multicolumn{2}{|c|}{}} & \multicolumn{2}{|l|}{$\begin{array}{l}\text { Unstandardized } \\
\text { Coefficients }\end{array}$} & $\begin{array}{l}\text { Standardized } \\
\text { Coefficients }\end{array}$ \\
\cline { 2 - 5 } \multicolumn{2}{|l|}{ Model } & $\mathrm{B}$ & Std. Error & Beta \\
\hline 1 & (Constant) & 3.468 & 1.169 & \\
& X1 & .338 & .071 & .346 \\
X2 & .382 & .089 & .463 \\
X3 & .103 & .092 & .120 \\
\multicolumn{2}{|c|}{ Sumber : SPSS 16 (Lampiran 3) }
\end{tabular}

Bentuk persamaan regresi dapat di tulis seperti berikut :

$\mathrm{Y}=3,468+0,338 \mathrm{X} 1+0,382 \mathrm{X} 2+$ $0,103 \mathrm{X} 3+\mathrm{e}$

Hasil persamaan regresi berganda tersebut menyampaikan bahwa :

1. Nilai konstant sebesar 3,468 artinya jika variabel yang diteliti, pada hakikatnya gaya hidup, kepribadian, dan kelas sosial diasumsikan bernilai nol maka keputusan pembelian tetap sebesar 3,468.

2. Nilai koefisien regresi gaya hidup terhadap keputusan pembelian 0,338 yang berarti jika gaya hidup bertambah sebesar satu satuan, maka keputusan pembelian akan meningkat sebesar 0,338 dengan ketentuan faktor-faktor lain di anggap tetap.

3. Nilai koefisien regresi kepribadian terhadap keputusan pembelian 0,382 yang berarti apabila kepribadian bertambah sebesar satu skala, maka keputusan pembelian akan meningkat sebesar 0,382 dengan ketentuan faktorfaktor lain di anggap tetap.

4. Nilai koefisien regresi kelas sosial terhadap keputusan pembelian 0,103 yang berarti apabila kelas sosial bertambah sebesar satu satuan, maka akan meningkatkan keputusan pembelian sebesar 0,103 dengan asumsi faktor-faktor lain di anggap tetap. 


\subsubsection{Uji Hipotesis}

\section{Uji F}

Pengujian ini dilakukan untuk melihat apakah variabel dependen dipengaruhi secara bersama-sama (simultan) oleh semua variabel independen. Uji F dilakukan untuk mengetahui pengaruh variabel independen gaya hidup, kepribadian, dan kelas sosial secara bersamaan terhadap variabel denpenden yaitu keputusan pembelian dari suatu persamaan regresi yang didasarkan pada nilai probabilitas $\mathrm{a}=0,05$.

Tabel 4.10

Hasil Uji F

\begin{tabular}{|l|l|l|l|l|l|}
\hline Model & $\begin{array}{l}\text { Sum of } \\
\text { Squares }\end{array}$ & Df & $\begin{array}{l}\text { Mean } \\
\text { Square }\end{array}$ & F & Sig. \\
\hline 1 Regression & 550.853 & 3 & 183.618 & 66.072 & $.000^{\mathrm{a}}$ \\
Residual & 226.787 & 96 & 2.779 & & \\
Total & 817.640 & 99 & & & \\
\hline
\end{tabular}

Sumber : SPSS 16 (Lampiran 3)

Nilai $F$ hitung sebesar 66,072 yang signifikan $0.000^{\mathrm{a}}$. Karena sig $<0,05$ ini berarti rumusan hipotesis yang membuktikan bahwa berpengaruh gaya hidup, kepribadian, dan kelas sosial secara simultan terhadap keputusan pembelian.

\section{Uji T}

Untuk melihat pengaruh perilaku individu terhadap komitmen organisasi, maka dilakukan pengujian hipotesis melalui uji t dengan hasil sebagai berikut :

Tabel 4.11

Hasil Uji T

\begin{tabular}{|c|c|c|c|c|c|}
\hline \multirow[b]{2}{*}{ Model } & \multicolumn{2}{|c|}{$\begin{array}{l}\text { Unstandardi } \\
\text { ed } \\
\text { Coefficients }\end{array}$} & \multirow{2}{*}{$\begin{array}{l}\begin{array}{l}\text { Standardized } \\
\text { Coefficients }\end{array} \\
\text { Beta }\end{array}$} & \multirow[b]{2}{*}{$\mathrm{T}$} & \multirow[b]{2}{*}{ Sig. } \\
\hline & B & $\begin{array}{l}\text { Std. } \\
\text { Error }\end{array}$ & & & \\
\hline $\begin{array}{l}1 \text { (Consta } \\
\text { nt) }\end{array}$ & 3.468 & 1.169 & & 2.966 & .004 \\
\hline $\mathrm{X} 1$ & .338 & .071 & .346 & 4.728 & .000 \\
\hline $\mathrm{X} 2$ & .382 & .089 & .463 & 4.302 & .000 \\
\hline X3 & .103 & .092 & .120 & 1.128 & .262 \\
\hline
\end{tabular}

Lampiran 3)
Berdasarkan hasil uji t pada tabel 4.11 dapat dilakukan analisa seperti berikut :

1. Hasil uji nilai Thitung gaya hidup sebesar 4,728 sedangkan besar nilai Ttabel sebesar 1.660. nilai Thitung besar dari Ttabel maka Ho ditolak (Ha diterima) dengan nilai signifikan sebesar $0,000<0,05$. Hal tersebut membuktikan bahwa keputusan pembelian dipengaruhi secara positif dan signifikan oleh gaya hidup.

2. Hasil uji nilai Thitung kepribadian sebesar 4,302 sedangkan besar nilai Ttabel sebesar 1.660. nilai Thitung besar dari Ttabel maka Ho ditolak (Ha diterima) dengan nilai signifikan sebesar $0,000<0,05$. Hal tersebut membuktikan kepribadian mempengaruhi secara positif san signifikan terhadap keputusan pembelian

3. Hasil uji nilai Thitung kelas sosial sebesar 1,128 sedangkan besar nilai Ttabel sebesar 1.660. nilai Thitung kecil dari Ttabel maka Ho diterima (Ha ditolak) dengan nilai signifikan sebesar $0,262>0,05$. Hal tersebut membuktikan bahwa keputusan pembelian tidak dipengaruhi positif dan signifikan oleh kelas sosial.

\section{Uji Koefisien Determinasi $\left(\mathbf{R}^{2}\right)$}

Pengujian koefisien determinasi $\left(\mathrm{R}^{2}\right)$ dilakukan untuk mengukur sejauh mana kemampuan model dalam menjelaskan variasi variabel dependen. Koefisien determinasi berkisar antara nol dan satu. Hal tersebut jika $\left(\mathrm{R}^{2}\right)=0$ membuktikan tidak ada pengaruh antar variabel dependen, apabila $\left(\mathrm{R}^{2}\right)$ semakin besar terhadap variabel dependen dan bila $\left(\mathrm{R}^{2}\right)$ semakin kecil mendekati 0 maka dapat disimpulkan semakin kecilnya pengaruh variabel independen terhadap variabel dependen. 
Tabel 4.12

Uji Koefisien Determinasi $\left(\mathbf{R}^{2}\right)$

\begin{tabular}{|l|l|l|l|l|}
\hline Model & $R$ & R Square & $\begin{array}{l}\text { Adjusted } \\
\text { R Square }\end{array}$ & $\begin{array}{l}\text { Std. Error of } \\
\text { the Estimate }\end{array}$ \\
\hline 1 & $.821^{\mathrm{a}}$ & .674 & .664 & 1.66704 \\
\hline
\end{tabular}

Pada tabel di atas di peroleh nilai adjusted $\mathrm{R}$ square adalah 0,664 artinya sebesar $66,4 \%$ variabel gaya hidup, kepribadian, dan kelas sosial mampu menjelaskan kepada keputusan pembelian dan sisanya $33,6 \%$ faktor lain yang mempengaruhinya tidak dilakukan pada penelitian ini.

\subsection{Pembahasan}

\subsubsection{Pengaruh Gaya Hidup terhadap}

Keputusan Pembelian Sepatu Merek Mollinic di PT. Ramayana

\section{Lestari Sentosa, Tbk Padang.}

Dari hasil uji regresi linear berganda dihasilkan bahwa keputusan pembelian 0,338 yang berarti jika gaya hidup bertambah sebesar satu skala, maka akan menambah keputusan pembelian sebesar 0,338 , Thitung gaya hidup sebesar 4,728 sedangkan besar nilai Ttabel sebesar 1.660. nilai Thitung besar dari Ttabel maka Ho ditolak (Ha diterima) dengan nilai signifikan sebesar $0,000<0,05$, artinya adanya kaitan gaya hidup pembeli terhadap keputusan pembelian, jika gaya hidup pembeli bertambah maka pembeli akan melakukan untuk membeli sepatu merek mollinic kembali.

4.5.2 Pengaruh Kepribadian terhadap Keputusan Pembelian Sepatu Merek Mollinic di PT. Ramayana Lestari Sentosa, Tbk Padang.

Dari hasil regresi berganda dihasilkan bahwa kepribadiaan terhadap keputusan pembelian 0,382 yang berarti apabila kepribadian bertambah sebesar satu skala, maka akan menambah keputusan pembelian sebesar 0,382, Hasil uji nilai Thitung kepribadian sebesar 4,302 sedangkan besar nilai Ttabel sebesar 1.660. nilai Thitung besar dari Ttabel maka Ho ditolak (Ha diterima) dengan nilai signifikan sebesar $0,000<0,05$, artinya apabila kepribadian konsumen bertambah maka keputusan untuk membeli kembali sepatu merek mollinic juga bertambah.

\subsubsection{Pengaruh Kelas Sosial terhadap} Keputusan Pembelian Sepatu Merek Mollinic di PT. Ramayana Lestari Sentosa, Tbk Padang.

Dari hasil analisis regresi linear berganda dengan hasil kelas sosial terhadap keputusan pembelian 0,103 yang berarti apabila kelas sosial bertambah sebesar satu skala, maka akan menambah keputusan pembelian sebesar satu satuan, nilai Thitung kelas sosial sebesar 1,128 sedangkan besar nilai Ttabel sebesar 1.660. nilai Thitung kecil dari Ttabel maka Ho diterima (Ha ditolak) dengan nilai signifikan sebesar 0,262>0,05, artinya apabila kelas sosial berkurang dalam masyarakat maka tidak adanya hubungan antara kelas sosial dengan keputusan pembelian untuk membeli kembali sepatu merek mollinic.

\section{PENUTUP}

\section{Kesimpulan}

Dilihat hasil penelitian maka dapat disimpulkan seperti berikut:

1. Dari hasil uji regresi linear berganda dihasilkan bahwa keputusan pembelian 0,338 yang berarti jika gaya hidup bertambah sebesar satu skala, maka akan menambah keputusan pembelian sebesar 0,338, Thitung gaya hidup sebesar 4,728 sedangkan besar nilai Ttabel sebesar 1.660. nilai Thitung besar dari Ttabel maka Ho ditolak (Ha diterima) dengan nilai signifikan sebesar $0,000<0,05$, artinya adanya hubungan gaya hidup konsumen terhadap keputusan pembelian, jika gaya hidup konsumen bertambah maka konsumen akan menentukan untuk membeli sepatu merek mollinic kembali.

2. Dari hasil regresi berganda dihasilkan bahwa kepribadiaan terhadap keputusan pembelian 0,382 yang berarti apabila kepribadian bertambah sebesar satu 
3. skala, maka akan menambah keputusan pembelian sebesar 0,382, Hasil uji nilai Thitung kepribadian sebesar 4,302 sedangkan besar nilai Ttabel sebesar 1.660. nilai Thitung besar dari Ttabel maka Ho ditolak (Ha diterima) dengan nilai signifikan sebesar $0,000<0,05$, artinya apabila kepribadian konsumen bertambah maka keputusan untuk membeli kembali sepatu merek mollinic juga bertambah.

4. Dari hasil analisis regresi linear berganda dengan hasil kelas sosial terhadap keputusan pembelian 0,103 yang berarti apabila kelas sosial bertambah sebesar satu skala, maka akan menambah keputusan pembelian sebesar satu satuan, nilai Thitung kelas sosial sebesar 1,128 sedangkan besar nilai Ttabel sebesar 1.660. nilai Thitung kecil dari Ttabel maka Ho diterima (Ha ditolak) dengan nilai signifikan sebesar $0,262>0,05$, artinya apabila kelas sosial berkurang dalam masyarakat maka tidak adanya hubungan antara

\section{DAFTAR PUSTAKA}

Ainun Jariah. (2012). Analisis FaktorFaktor Pribadi Yang Mempengaruhi yang mempengaruhi keputusan pembelian sepeda motor yamaha di lumajang.

Arikunto, Suharsimi. (2002). Metodologi Penelitian. Penerbit PT. Rineka Cipta. Jakarta.

Hamid, A., \& Sriwijaya, P. N. (n.d.). Pengaruh Kepribadian dari Faktor Individu Terhap Keputusan Pendenga Memilih Lembaga Penyiar Radio Swasta DI Palembang.

Huda, N., \& Rifani, A. (n.d.). Faktor kebudayaan, kelas sosial, sikap, kepribadian dan persepsi yang mempengaruhi

keputusan kelas sosial dengan keputusan konsumen untuk membeli ulang sepatu merek mollinic.

\section{Saran}

Berdasarkan kepada kesimpulan penelitian yang sudah dilaksanakan maka disampaikan sebagian saran yang bisa memberikan manfaat positif sebagai berikut:

1. Diharapkan menggunakan alat uji yang berbeda pada penelitian selanjutnya.

2. Diharapkan kepada peneliti selanjutnya, untuk dapat menggunakan penelitian ini sebagai referensi dan perbandingan dalam melaksanakan penelitian pada bidang yang sama di waktu tertentu.

3. Bagi peneliti agar dapat mengkaji lebih dalam wawasan dan pendalaman pengetahuan dalam manajemen pemasaran khususnya yang berhubungan dengan Mengetahui Pengaruh faktor Fisikografis terhadap keputusan pembelian.

pembelian kain sasirangan di kotamadya banjarmasin.

Marlius, D. (2017). Keputusan Pembelian Berdasarkan Faktor Psikologis Dan Bauran Pemasaran Pada PT. Intercom Mobilindo Padang. Jurnal Pundi. Volume 1. No. 1. Hal. 57-66. https://doi.org/10.31575/jp.v1i1.9

Marlius, D. (2016). Pengaruh Bauran Pemasaran Jasa Terhadap Minat Nasabah Dalam Menabung Pada Bank Nagari Cabang Muaralabuh. https://doi.org/10.31227/osf.io/vd qgx

Putri, P. kartana. (2011). Pengaruh Faktor Sosial dan Psikografis terhadap Keputusan Mahasiswa Melakukan Registrasi Akademik ( Studi pada Mahasiswa Universitas Dian Nuswantoro Terdaftar dan Aktif Tahun Akademik 2010 /2011) 
Priyanti,Y. Susanti, F. Aziz, N. (2017). Minat Beli Konsumen Toko Sepatu Bata Dipasar Raya Padang Dilihat Dari Sikap Dan Iklan. Jurnal Pundi, Vol. 01, No. 02

Rozikin, Hasiolan, L. B., \& Haryono, A. T. (2015). Pengaruh Harga, Iklan Televisi Dan Kelas Sosial Terhadap Keputusan Pembelian Mobil Avanza Di Dealer Nasmoco Pemuda Semarang. Journal of Management, 1.

Satria, E. (2015). Pengaruh Gaya Hidup Terhadap Keputusan Pembelian Handphone Merek Blackberry Di Kota Sungai Penuh Jambi.

Sugiyono. (2012). Metode Penelitian Kuantitatif Kualitatif dan $R \& D$ Bandung : Alfabeta.

Susanti, F. (2018). Kesenangan, Dorongan Berbelanja Dan Merek Terhadap Intensi Berbelanja Online Produk Fashion (Studi Pada Mahasiswi STIE "KBP" Padang). Jurnal Pundi, Vol. 01, No. 03 